\title{
Ultrastructural Characterization of Normal and Damaged Membranes of Mycobacterium leprae and of Cultivable Mycobacteria
}

\author{
By MANUEL T. SILVA* and PAUla M. MACEDO \\ Centro de Citologia Experimental da Universidade do Porto, Rua do Campo Alegre 1021, \\ 4100 Porto, Portugal
}

(Received 20 July 1983; revised 5 October 1983)

\begin{abstract}
Microdensitometry showed that the membrane profiles of normal cultivable mycobacteria were very asymmetric (outer layer denser and thicker than the inner layer), while the profiles of normal-looking $M$. leprae in lepromatous patients, in experimentally infected armadillos and in nude mice were approximately symmetric; moreover, the membrane of $M$. leprae was thicker than that of cultivable species. Using two cytochemical methods for the ultrastructural detection of periodic acid-Schiff (PAS)-positive molecules (the Thiery procedure, and staining with phosphotungstic acid at low $\mathrm{pH}$ ) we found that the membrane of cultivable mycobacteria, growing in vitro or in vivo, had PAS-positive components exclusively in the outer layer, while the normal-looking $M$. leprae in patients and in armadillos had membranes with PAS-positive components in both layers. The membranes of damaged cultivable mycobacteria, in vivo or in vitro, and of damaged $M$. leprae, in patients or armadillos, were PAS-negative.
\end{abstract}

\section{INTRODUCTION}

In previous publications (Silva \& Macedo, 1982a, 1983a; Silva et al., 1982a) we reported that the ultrastructural profile seen in lead-stained ultrathin sections of the membrane of ultrastructurally normal $M$. leprae, in patients with lepromatous leprosy (LL) and in experimentally infected armadillos, was symmetric. This pattern contrasted with that found in all normal Gram-positive bacteria, including acid-fast bacteria, studied so far (Silva, 1967, 1971, 1975, 1984; Silva \& Macedo, 1982a, 1983b), and, consequently, represented a rather peculiar characteristic of the leprosy bacillus. We recently found that the symmetric membrane of normal-looking $M$. leprae had PAS-positive components in both layers, while the cultivable mycobacteria studied had such components only in the outer layer (Silva \& Macedo, 1983c). In the present paper we describe the results of a more detailed study of the membranes of normal and degenerating $M$. leprae in comparison with the membranes of normal and degenerating cultivable mycobacteria, using cytochemical methods for the detection of PAS-positive molecules and microdensitometry. Some of these results have been presented in abstract form (Silva \& Macedo, 1982b).

\section{METHODS}

Bacterial strains and growth conditions. For the study of in vitro cultures, the strains listed in Table 1 were grown in TB or $7 \mathrm{H} 9$ broth (Difco) to late-exponential phase, at $37^{\circ} \mathrm{C}$ (except for $\boldsymbol{M}$. marinum, which was incubated at $30^{\circ} \mathrm{C}$ ), with shaking twice a day. Mycobacterium lepraemurium was grown in Ogawa's egg yolk medium at $35^{\circ} \mathrm{C}$ for 5 weeks (Portaels \& Pattyn, 1981).

Mycobacterium lepraemurium (Douglas strain) was studied $(a)$ in homogenates from rat lymph nodes (kindly supplied by Dr P. Lagrange, Institut Pasteur, Paris); and (b) after inoculation in the peritoneal cavity of mice

\footnotetext{
Abbreviations: LL, lepromatous leprosy; PAS, periodic acid-Schiff; PTA, phosphotungstic acid; MI, morphological index (Jopling, 1978); BI, bacteriological index (Jopling, 1978).
} 
Table 1. Cultivable Mycobacterium strains used

\author{
M. smegmatis (ATCC 14468; IPP 141330001) \\ $M$. aurum (strain $\mathrm{A}^{+}$; IPP 141210005) \\ $M$. scrofulaceum (strain HB1565; IPP 140220031) \\ M. fortuitum (strain HB1792; IPP 140410002) \\ M. szulgai (strain HB5728; IPP 140220031) \\ $M$. chelonei subsp. chelonei (strain 810099 ; \\ IPP 140420019) \\ $M$. chelonei subsp. abcessus (strain 810192; \\ IPP 140420020) \\ $M$. triviale (strain T-254-3; IPP 140330002) \\ M. simiae (ATCC 25275; IPP 141020001 bis)
}

\author{
M. marinum (ATCC 927; IPP 140120001) \\ M. gordonae (ATCC 14470; IPP 140210001) \\ $M$. flavescens (ATCC 14474; IPP 140230001) \\ M. tuberculosis (strain H37Rv; IPP 140010001) \\ $M$. tuberculosis (strain H37Ra NCTC 7417; M6710, \\ IMT) \\ M. terrae (strain W45; IPP 140320001) \\ $M$. lepraemurium (strain Douglas, Dr P. Lagrange, \\ IPP) \\ M. lepraemurium (strain 'cat leprosy' 406, IMT)
}

IPP, Institut Pasteur, Paris; IMT, Institut de Médecine Tropicale, Antwerpen.

Table 2. Samples from experimentally infected armadillos used

\begin{tabular}{|c|c|c|c|c|}
\hline \multirow{8}{*}{$\begin{array}{l}\quad \text { Sample } \\
\text { Liver } \\
\text { Liver } \\
\text { Liver } \\
\text { Liver } \\
\text { Liver } \\
\text { Liver } \\
\text { Skin leproma }\end{array}$} & $\begin{array}{c}\text { Sample } \\
\text { preparation }\end{array}$ & Origin & Armadillo & Supplied by \\
\hline & Homogenate & Dr G. P. Walsh* & no. 6 & \multirow{7}{*}{ Dr F. Portaels, IMT } \\
\hline & Homogenate & Dr Y. Robint & $\mathrm{AJ}$ & \\
\hline & Homogenate & Dr C. C. Shepard $\ddagger$ & no. 31 & \\
\hline & Homogenate & Dr R. J. W. Rees§ & $2457 / 10$ & \\
\hline & Isolated bacilli & Dr Y. Robin & $\mathrm{AU}$ & \\
\hline & Tissue fragments & Dr Y. Robin & AU & \\
\hline & Tissue fragments & Dr Y. Robin & $\mathrm{AU}$ & \\
\hline & $\begin{array}{l}\text { * Armed Forc } \\
\dagger \text { Institut Past } \\
\ddagger \text { Communica } \\
\S \text { National In }\end{array}$ & $\begin{array}{l}\text { Caytitute of Pathology } \\
\text { Cayene, French G } \\
\text { Disease Center, Atla } \\
\text { te for Medical Rese }\end{array}$ & $\begin{array}{l}\text { hington, D } \\
\text { Sa., USA. } \\
\text { London. }\end{array}$ & \\
\hline
\end{tabular}

(strain Charles River CD-1); samples of peritoneal exudate taken after 5 months contained many macrophages with mostly normal bacilli. Mycobacterium tuberculosis H37Rv was studied after intraperitoneal inoculation in mice (same strain as above); after $8 \mathrm{~d}$ the peritoneal exudate contained mostly normal bacilli inside macrophages. Mycobacterium marinum was inoculated in the hind foot pads of mice (same strain as above) where a self-limiting infection develops; multiplying bacilli are present during the initial phase of the infection (up to about $7 \mathrm{~d}$ ) (Colston \& Hilson, 1976).

Mycobacterium leprae cells were studied in the following. (a) Skin biopsies from 15 patients with lepromatous leprosy (Ridley \& Jopling, 1964), including 7 without anti-leprosy treatment; this group of untreated patients includes the 4 patients already described in a previous publication (Silva et al., 1982a). Patients nos. 2, 4, 5 and 7 were selected for detailed ultrastructural study because they had great numbers of acid-fast bacilli in skin smears (BI $5+$ or $6+$ ) and a significant proportion of the bacilli stained solidly by the Ziehl-Neelsen technique (MI between $13 \%$ and $37 \%$ ). (b) Biopsies from experimentally infected armadillos (Table 2). (c) Homogenates of nude mouse foot pads (kindly supplied by Dr Françoise Portaels, Institut de Médecine Tropicale, Antwerpen, Belgium).

Study of damaged membranes of cultivable mycobacteria. Mycobacterium tuberculosis $\mathrm{H} 37 \mathrm{Rv}, M$. marinum and $M$. aurum cultures in TB broth (Difco) were incubated long enough to enter the decline phase during which increasing numbers of autolysing cells occur. Exponentially growing $M$. tuberculosis H37Ra in TB broth (Difco) was exposed to rifampin $\left(10 \mu \mathrm{g} \mathrm{ml}^{-1}\right)$ or to sodium azide $(75 \mathrm{mM})$ and samples were taken at intervals. Mycobacterium tuberculosis $\mathrm{H} 37 \mathrm{Ra}$, grown exponentially as above, was broken by sonication in a Branson sonifier model W185D operated at $100 \mathrm{~W}$; the samples were kept in ice during sonication cycles.

Degenerating $M$. tuberculosis $\mathrm{H} 37 \mathrm{Ra}$ and $M$. marinum, in mouse peritoneal macrophages and in mouse foot pads, respectively, were obtained from samples collected in the regressive phase of the infection; lysing bacilli were largely predominant $4 \mathrm{~d}$ after inoculation with $M$. tuberculosis $\mathrm{H} 37 \mathrm{Ra}$ and $9 \mathrm{~d}$ after inoculation with $M$. marinum.

Electron microscopy. Bacteria from broth cultures were collected by centrifugation $(2500 \mathrm{~g}$ for $10 \mathrm{~min})$. Mycobacterium lepraemurium was scraped from the surface of Ogawa's medium. Macrophages with phagocytosed mycobacteria were collected from the peritoneal cavity using previously described methods (Cohn \& Benson, 1965). Mycobacterium marinum in the mouse foot pads were taken by scraping the purulent exudate underneath the 
skin. Skin biopsies from LL patients were fixed immediately after being taken. Samples from experimentally infected armadillos were either kept at $-70^{\circ} \mathrm{C}$ until fixation or fixed immediately. Homogenates of nude mouse foot pads were kept at $-70^{\circ} \mathrm{C}$ until fixation.

All samples were fixed with $4 \%(\mathrm{w} / \mathrm{v})$ formaldehyde $/ 1 \cdot 25 \%(\mathrm{w} / \mathrm{v})$ glutaraldeyde $/ 10 \mathrm{~mm}-\mathrm{Ca}^{2+}$, followed by $1 \%$ $(\mathrm{w} / \mathrm{v}) \mathrm{OsO}_{4} / 10 \mathrm{mM}-\mathrm{Ca}^{2+}$, followed by $0.5 \%(\mathrm{w} / \mathrm{v})$ uranyl acetate in veronal/acetate buffer or in water (Silva $\&$ Macedo, 1982a). After dehydration in ethanol, the samples were embedded in Epon (Luft, 1961). Ultrathin sections were stained with lead citrate (Venable \& Coggeshall, 1965) for $5 \mathrm{~min}$ or stained for PAS-positive molecules. For this purpose, we used two different procedures. (a) The Thiéry technique (Thiéry, 1967; Thiéry \& Rambourg, 1974) done as follows: $1 \%(w / v)$ periodic acid, $30 \mathrm{~min} ; 1 \%(\mathrm{w} / \mathrm{v})$ thiosemicarbazide, $60 \mathrm{~min} ; 1 \%(\mathrm{w} / \mathrm{v})$ silver proteinate or $1 \%(\mathrm{w} / \mathrm{v})$ silver vitelinate (Silva et al., $1982 \mathrm{~b}$ ), $30 \mathrm{~min}$. The washings were done as described by Thiéry (1967). In all experiments duplicate grids were pretreated with $3 \%(w / v)$ hydrogen peroxide before the Thiéry procedure to ensure complete removal of bound osmium (Robertson et al., 1975). Control tests were performed by treating sections with $0 \cdot 1 \%(\mathrm{w} / \mathrm{v})$ sodium borohydride (Robertson et al., 1975) between periodic acid oxidation and thiosemicarbazide treatment and by omitting periodic acid or thiosemicarbazide treatments. $(b)$ PTA at low pH (Rambourg, 1971; Rosseau \& Hermier, 1975) done as follows: $1 \%(\mathrm{w} / \mathrm{v})$ periodic acid, $15 \mathrm{~min}$, followed by $1 \%(\mathrm{w} / \mathrm{v})$ phosphotungstic acid in $1 \mathrm{M}-\mathrm{HCl}, 15 \mathrm{~min}$, without subsequent wash; as control, sections were treated with $1 \%(\mathrm{w} / \mathrm{v})$ phosphotungstic acid at $\mathrm{pH} 7 \cdot 0$. Observations were made with Siemens electron microscopes (Elmiskop IA and 102).

Tracings of membrane profiles were made on photographic negatives of lead-stained sections with a JoyceLoebl MK III CS microdensitometer, set to an arm ratio of $50 \times$ and a slit width of $0.5 \mathrm{~nm}$. The microscopes were calibrated with a grating grid.

Definition of normal and altered mycobacterial cells. One of the essential aspects of the present work deals with the comparison of the membrane ultrastructure in normal and damaged mycobacteria. The ultrastructural criteria, as seen in lead-stained sections, used to label the bacilli as normal or degenerating were the following, as previously discussed (Silva \& Macedo, 1983b): normal mycobacterial cells have continuous cell wall and cytoplasmic membrane, distinct ribosomes and fibrillar nucleoids (see Fig. 1 in Silva \& Macedo, 1983a; Fig. 1 in Silva \& Macedo, 1983b); degenerating cells are characterized by an intracellular compartment without ribosomes, with blocks of compact, homogeneous material, which is progressively degraded as cell lysis proceeds, and with dispersed DNA fibrils; this compartment is enveloped by a membrane that may exhibit partial solubilization (at the final stages of lysis it is completely solubilized); in cells with advanced degenerative alterations, the cell wall is distorted or discontinuous (see Figs 2 and 3 in Silva \& Macedo, 1983b; Figs 4a, $5 a, 5 b$ in Silva et al., 1982a). The characterization of mycobacterial cells as normal or degenerating in sections stained by the Thiéry or PTA procedures is more difficult because less morphological detail is visible; however, the distinction is still possible in most cases by using some of the criteria indicated for lead-stained sections, namely: continuity of membranes and cell wall and compactness of cytoplasm. Moreover, the proportion of normal versus damaged bacilli in leadstained preparations is a useful indication of the proportion of such bacillary forms in sections stained for PASpositive molecules in the same samples.

\section{RESULTS}

\section{Densitometry of mycobacterial membrane profiles}

In order to get quantitative information on mycobacterial membrane geometry we compared the densitometric tracings of membrane profiles in lead-stained sections of normal and degenerating bacilli. The results (Table 3, Fig. 1) showed that: (a) all normal-looking cells of the cultivable species studied (Table 1) had membranes with very asymmetric profiles, both in vitro and in vivo; $(b)$ normal-looking $M$. leprae cells, in armadillos, nude mice or patients had membranes with approximately symmetric profiles, with peak-to-peak distances higher than those of the cultivable species; (c) lysing cells of the cultivable species, both in vitro and in vivo, had approximately symmetric profiles.

\section{Ultrastructural detection of PAS-positive components in normal mycobacterial membranes}

Since the profile of the membrane of normal-looking $M$. leprae was symmetric because of the increase in density and thickness of its inner layer compared to that of the cultivable species (Fig. 1) the $M$. leprae membrane might have some additional components in its inner layer. The observation by Petitprez \& Derieux (1970) that the cultivable $M$. phlei has membranes with an asymmetric distribution of PAS-positive components, revealed by the Thiéry procedure, which parallels the asymmetry seen in lead-stained sections, prompted us to study the membranes of 
Table 3. Peak-to-peak distances from microdensitometric tracings of mycobacterial membranes in lead-stained Epon sections

The samples were fixed as described in Methods. Statistical analysis (Student's $t$ test) of the values for the peak-to-peak distances in the strains studied showed that: $(a)$ the difference between the thickness of the membrane of $M$. leprae and those of all the cultivable species is highly significant $(P<0.001)$; (b) there is no significant difference in membrane thickness between the cultivable species $(P>0.05)$.

$\begin{array}{cc}\text { No. of } & \text { Peak-to-peak distance } \\ \text { Bacterium } & \text { and SD (nm) }\end{array}$

$\begin{array}{lll}\begin{array}{l}\text { M. leprae* } \\ \text { (in LL patients and armadillos) }\end{array} & 90 & 7.05 \pm 0.50 \\ \begin{array}{l}M . \text { tuberculosis H37Ra } \\ \text { in vitro (TB broth) } \\ \text { in vivo (mouse macrophages) }\end{array} & 13 & 6.36 \pm 0.22 \\ \begin{array}{l}M \text {. lepraemurium } \\ \text { in vivo (mouse macrophages) }\end{array} & 12 & 6.48 \pm 0.45 \\ \begin{array}{l}M \text {. aurum } \\ \text { in vitro (TB broth)* }\end{array} & 33 & 6.45 \pm 0.23 \\ \text { Average values for the cultivable species } & 16 & 6.37 \pm 0.37 \\ & 74 & 6.42 \pm 0.31\end{array}$

* Values taken from Silva \& Macedo (1983c).

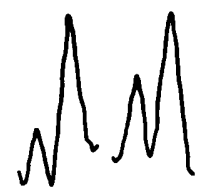

(a) (b)

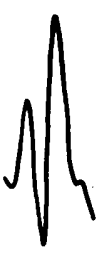

(c)

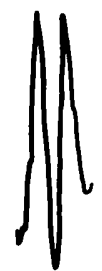

(d)

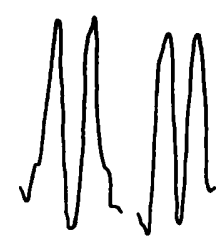

(e) $(f)$

Fig. 1. Microdensitometric tracings of mycobacterium membranes. The peaks corresponding to the outer layer are on the right side of each tracing. (a) Normal $M$. tuberculosis $\mathrm{H} 37 \mathrm{Ra}$, in vitro (TB broth); (b) normal $M$. tuberculosis $\mathrm{H} 37 \mathrm{Ra}$, in vivo (mouse macrophage); (c) normal $M$. lepraemurium (Douglas strain), in vivo (mouse macrophage); (d) lysed $M$. lepraemurium (Douglas strain), in vivo (mouse macrophage); (e) normal $M$. leprae, in patient no. 2; $(f)$ lysed $M$. leprae, in patient no. 2.

normal mycobacteria by the same procedure. We found that both layers of the membrane of normal-looking $M$. leprae in patients and in armadillos (Silva \& Macedo, 1983c) stained strongly, irrespective of pretreatment with hydrogen peroxide (Fig. $2 a, b$ ), while only the outer layer of the membrane was stained in all the cultivable strains studied, namely $M$. tuberculosis $\mathrm{H} 37 \mathrm{Rv}$ and $\mathrm{H} 37 \mathrm{Ra}, M$. marinum, $M$. lepraemurium, $M$. aurum, $M$. terrae, $M$. smegmatis, grown in vitro (Silva \& Macedo, $1983 c$ )(Figs $3 a, 3 c, 5 b, 5 c$ ) and $M$. chelonei subsp. chelonei, $M$. szulgai, $M$. simiae, $M$. fortuitum and $M$. flavescens, grown in vitro.

A similar staining pattern was observed with the PTA technique (Figs $2 c, 3 b$ ), although the interpretation of the results with that method is sometimes more difficult than with the Thiéry procedure, because the PTA staining is more diffuse; moreover, since this technique stains the cell wall, the membrane may be difficult to resolve whenever it is closely apposed to the wall (Fig. 2c).

We considered the possibility that the symmetric profile of $M$. leprae membrane might be due to the particular environment in which the bacilli grow, that is, inside macrophages of the naturally or experimentally infected hosts. We therefore studied the membrane profiles of $M$. tuberculosis $\mathrm{H} 37 \mathrm{Ra}$ and $\mathrm{H} 37 \mathrm{Rv}$ and $M$. lepraemurium multiplying inside mouse peritoneal macrophages and those of $M$. marinum in mouse foot pads. Again, we found in bacilli with normal ultrastructure an asymmetric staining of the membrane by the Thiéry and PTA procedures (Fig. $4 a-d$ ). 


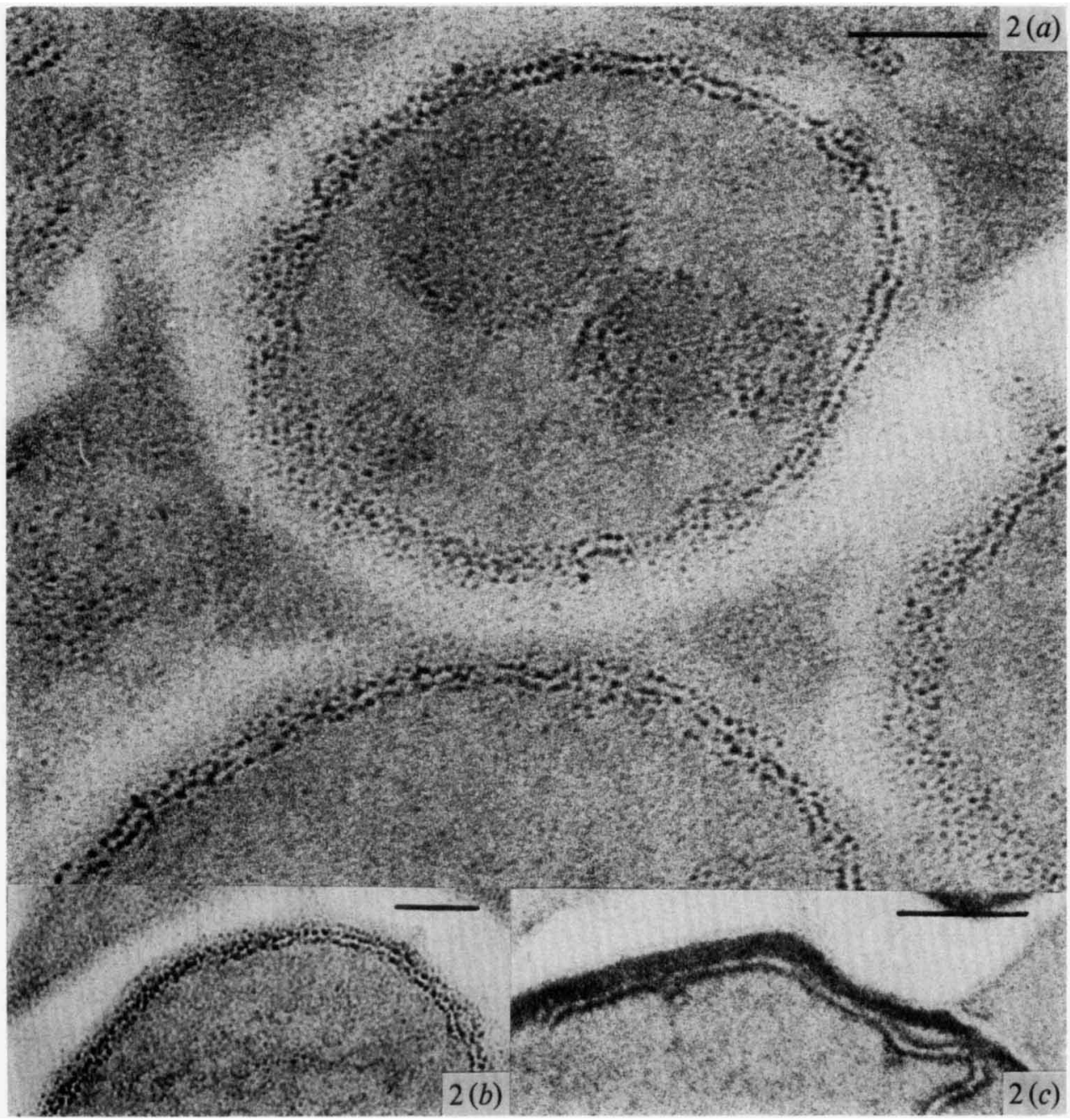

Fig. 2. Mycobacterium leprae cells stained by the Thiéry procedure, showing PAS-positive symmetric staining of membrane profiles. (a) Skin biopsy from patient no. 7. (b) Same sample as in (a), but section treated with hydrogen peroxide before use of the Thiéry procedure. $(c)$ Same sample as above, stained by PTA at low pH; note that the wall is densely contrasted and that the symmetric staining of the membrane is visible only in the part of the membrane that is separated from the wall. In this and in all other figures the bar markers represent $100 \mathrm{~nm}$.

We found that the positive Thiéry staining exhibited by the membranes of the mycobacteria studied, including $M$. leprae and the cultivable species, had the following characteristics: $(a)$ it was abolished by the reduction of aldehydes with sodium borohydride; $(b)$ it was observed in sections pretreated with hydrogen peroxide (Fig. $2 b) ;(c)$ it was not observed when the periodic acid or the thiosemicarbazide treatments were omitted. These results indicated that the silver staining was probably revealing polysaccharide residues (Robertson et al., 1975; Thiéry, 1967; Thiéry \& Rambourg, 1974). PTA at pH 7.0 did not stain the membranes of the mycobacteria studied. Although the mechanism of PTA staining at low $\mathrm{pH}$ is not well established, it had been proposed that such staining reveals polysaccharides (Fléchon \& Huneau, 1974; Rambourg, 1971; Roland, 1974). 

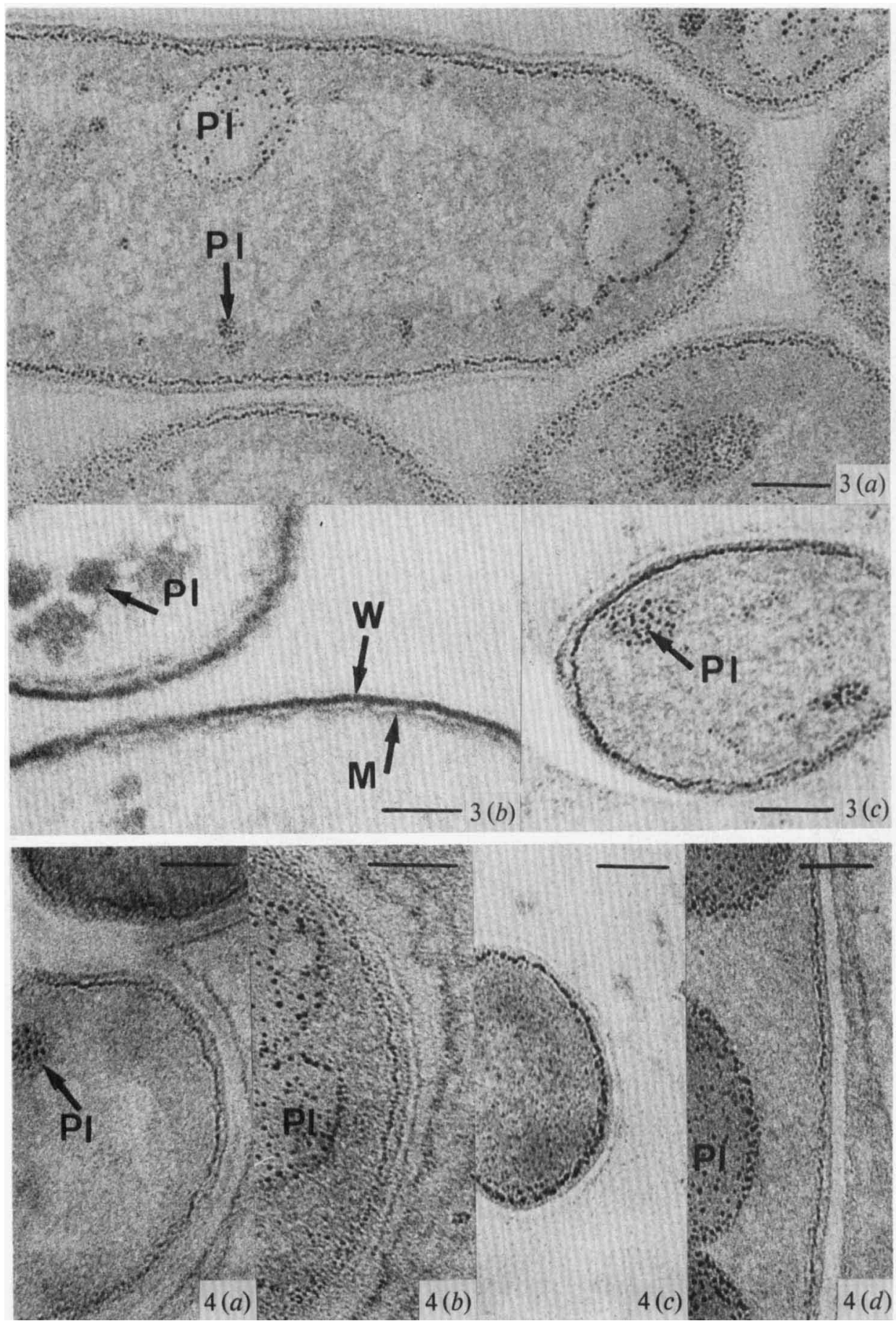

Fig. 3. Ultrastructural staining for PAS-positive molecules of in vitro grown mycobacteria. (a) $M$. terrae stained by the Thiéry procedure; (b) same sample stained by PTA at low $\mathrm{pH} ;(c) M$. lepraemurium stained by the Thiéry procedure. PI, PAS-positive inclusions; M, membrane with the outer layer preferentially stained; $\mathbf{W}$, cell wall.

Fig. 4. Asymmetric Thiéry staining of the membrane of in vivo grown $M$. tuberculosis $\mathrm{H} 37 \mathrm{Rv}(a), M$. tuberculosis H37Ra (b), M. lepraemurium (Douglas strain) (c), and $M$. marinum (d). PI, PAS-positive inclusions. 


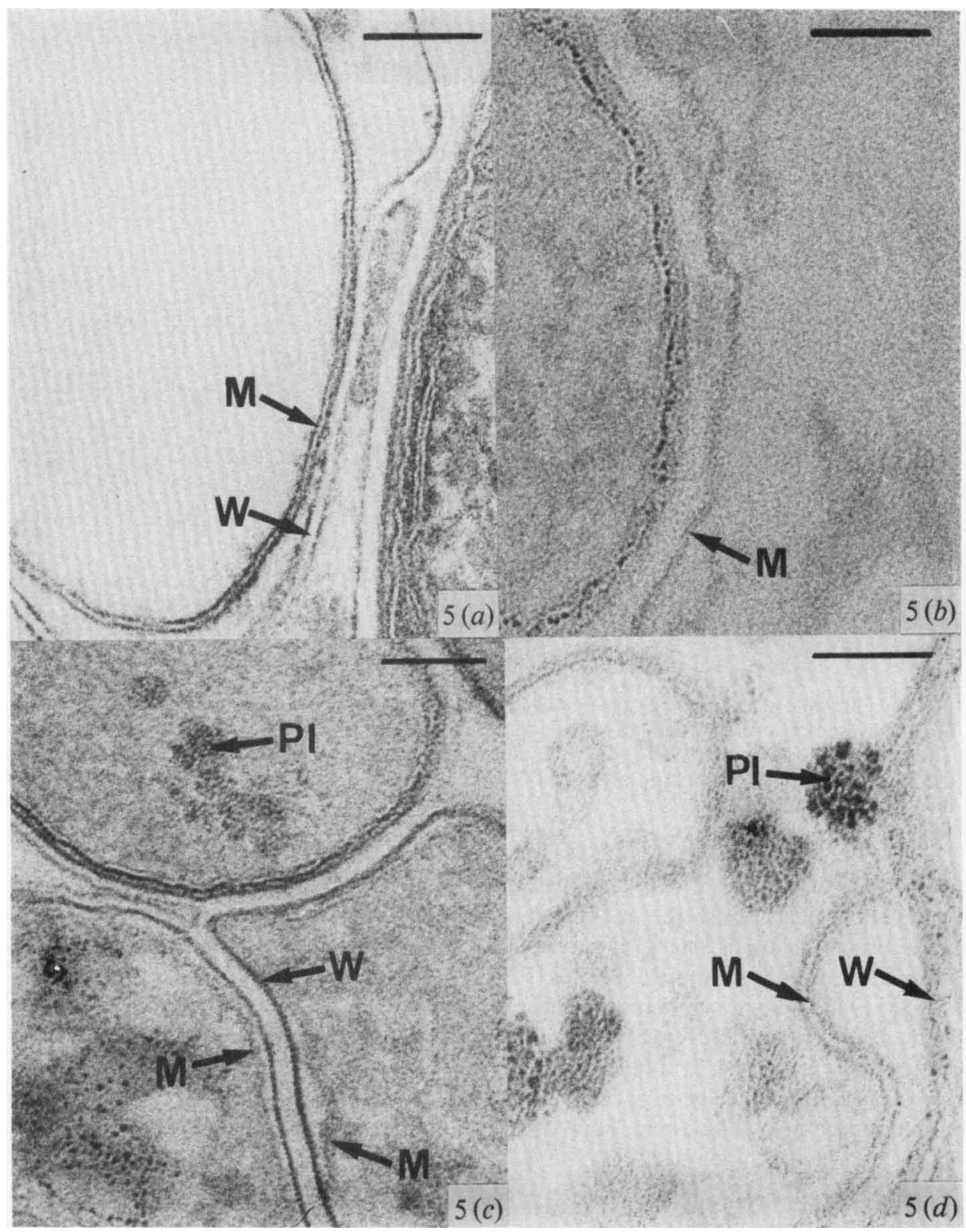

Fig. 5. In vitro autolysing mycobacterial cells. (a) $M$. tuberculosis $\mathrm{H} 37 \mathrm{Rv}$, section stained with lead; the membrane is symmetric. (b) Same sample stained by the Thiéry procedure; the cell on the left is normal and has a membrane with the outer layer Thiéry positive; on the right side the membrane remnants of a lysed cell are Thiéry-negative. $(c) M$. marinum, section stained by the Thiéry procedure; the cell at the top is normal and its membrane has a Thiéry-positive outer layer; the lower two cells are lysed and their membranes (M) are Thiéry-negative. $(d) M$. aurum under advanced lysis; the membrane (M) is Thiérynegative. W, cell wall; PI, PAS-positive inclusions.

A systematic survey of samples from the $15 \mathrm{LL}$ patients, including 7 not subjected to antileprosy treatment, never showed bacilli with an asymmetric staining of membranes. Careful study of samples from armadillos experimentally infected with $M$. leprae showed Thierysymmetric membranes, except for a few bacilli in the liver of armadillo AU (Table 2) which contained Thiéry-asymmetric membranes. 


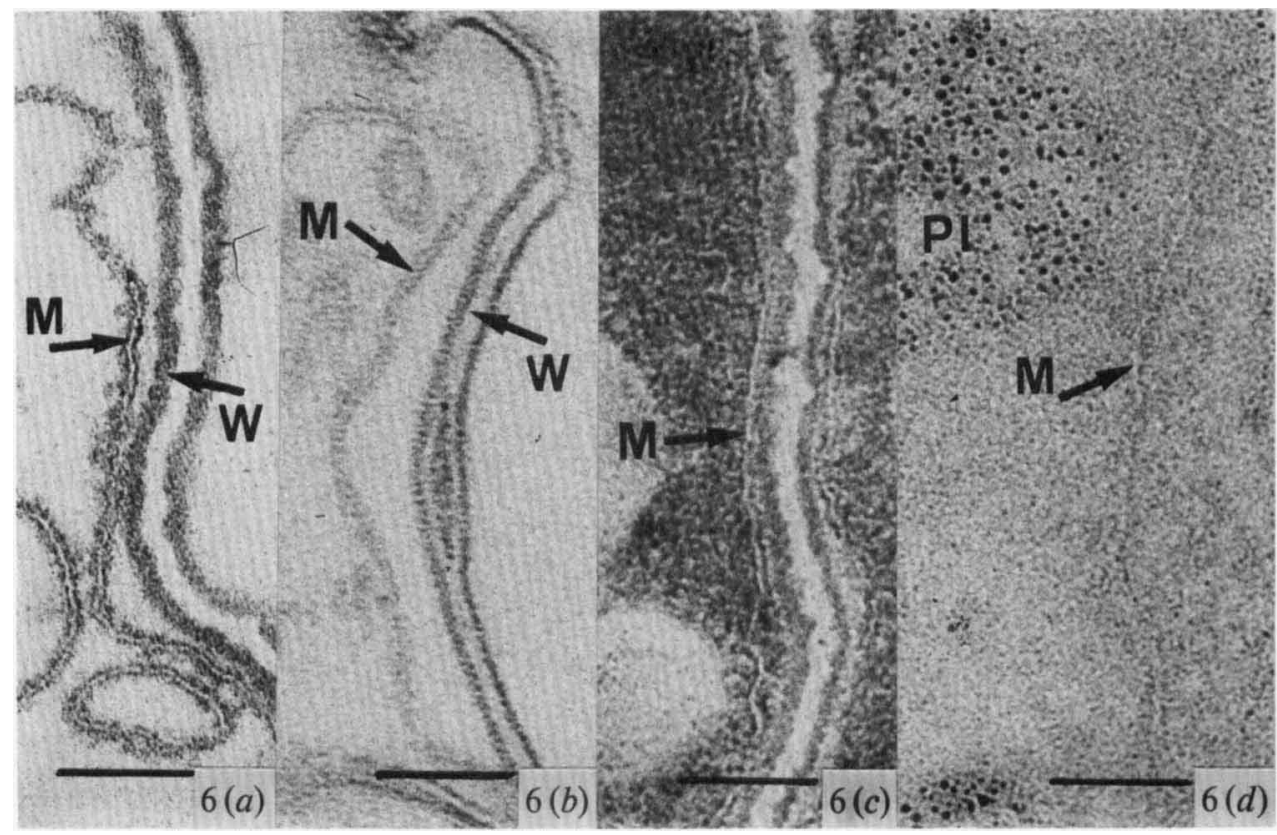

Fig. 6. Cultivable mycobacterial cells damaged by different treatments. $(a, b)$ M. tuberculosis H37Ra, broken by sonication; the membrane $(\mathrm{M})$ is approximately symmetric after lead staining $(a)$ and Thiéry-negative $(b) .(c, d) M$. tuberculosis $\mathrm{H} 37 \mathrm{Ra}$ exposed to $75 \mathrm{mM}$-sodium azide in TB broth for $4 \mathrm{~d}$; the membrane $(M)$ is symmetric after lead staining $(c)$ and Thiéry-negative $(d)$. PI, PAS-positive inclusions; $\mathbf{W}$, cell wall.

\section{Ultrastructure and cytochemistry of damaged mycobacterial membranes}

In lead-stained sections, the membranes of cultivable species undergoing degenerative processes, either in vitro or in vivo, or subjected to membrane-damaging treatments, as indicated in Methods, exhibited symmetric profiles (Figs $5 a, 6 a, 6 c$ ), as briefly reported elsewhere (Silva $\&$ Macedo, 1983b). Such symmetric membranes were Thiéry-negative (Figs $5 b-d, 6 b, 6 d, 7 a$, $7 b$ ), indicating that the PAS-positive residues, which in normal membranes are present in the outer layer, had been lost or modified.

Mycobacterium leprae cells, in patients or in armadillos, with ultrastructural signs of advanced degenerative alterations also had Thiéry-negative, symmetric membranes (Fig. 7c, d).

\section{DISCUSSION}

As previously discussed (Silva, 1971, 1975, 1984; Silva \& Macedo, 1982a, 1983a, b), in order to define the membrane ultrastructural profile of Gram-positive bacteria, including mycobacteria, it is essential to consider two aspects: (a) the fixation conditions used to prepare the samples for electron microscopy, because such conditions markedly influence the micromorphological pattern of membranous structures, and $(b)$ the condition of the bacterial cells, because in properly fixed samples normal and altered membranes have different profiles. Regarding point $(a)$, we have investigated the influence of several fixation parameters on the final electron microscopic image of bacterial membranes and have developed a fixation procedure that, on the basis of morphological, chemical and functional grounds; we consider to preserve bacterial membranes satisfactorily (Silva \& Macedo, 1982a, 1983b); such a fixation procedure was used in the present study. Regarding point $(b)$, we had observed that the membranes of all normal Gram-positive bacteria studied, including members of the genera Bacillus, Streptococcus, Micrococcus, Sarcina, Sporosarcina, Listeria, Streptomyces, Nocardia and cultivable Mycobacterium, when fixed according to the conditions previously found to be 


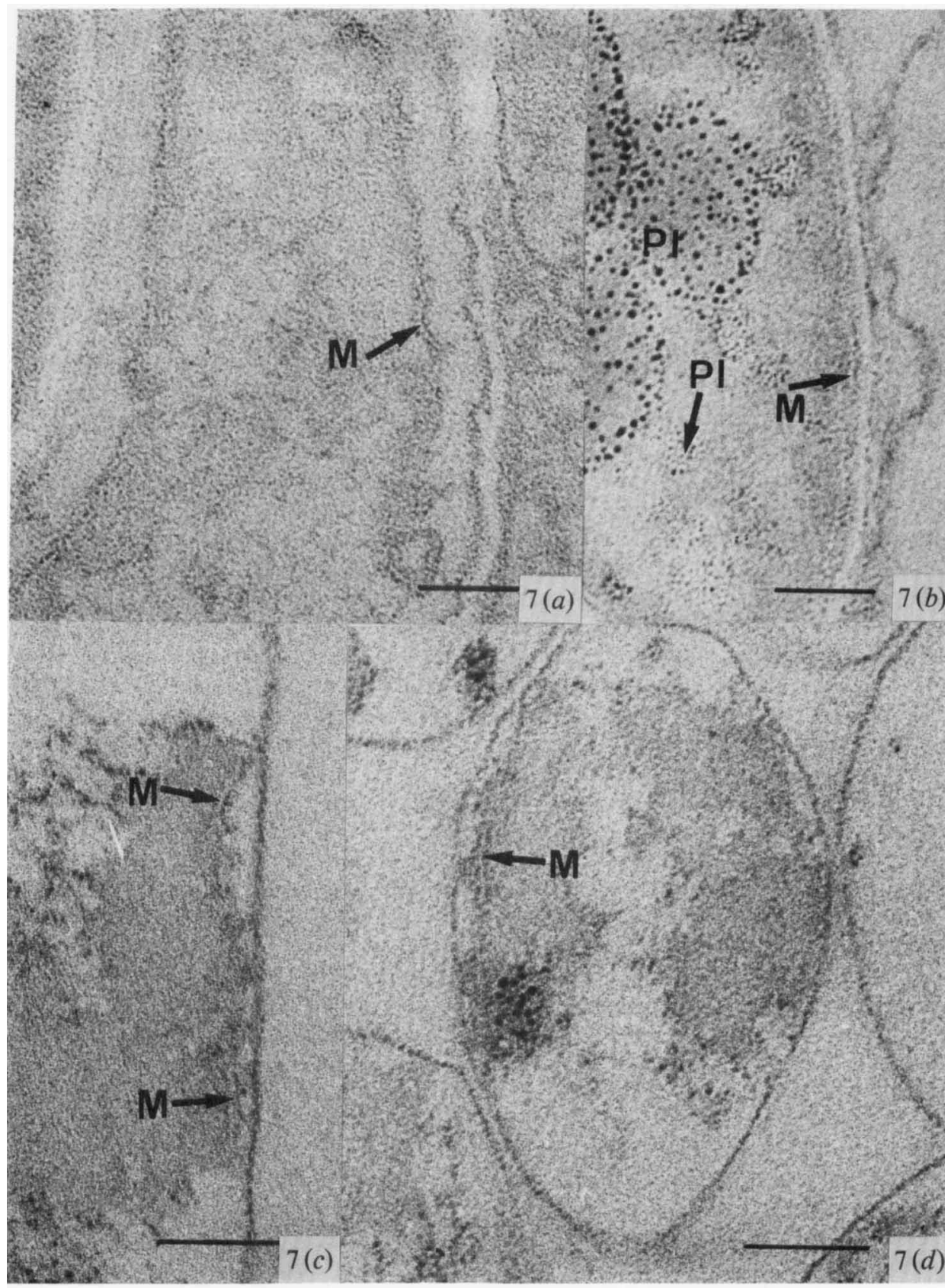

Fig. 7. Thiéry staining of mycobacterial cells under lysis in infected hosts. (a) M. marinum in mouse foot pads after $15 \mathrm{~d}$ infection; the membrane (M) is Thiéry-negative. (b) $M$. tuberculosis $\mathrm{H} 37 \mathrm{Ra}$ in mouse peritoneal macrophages after $8 \mathrm{~d}$ infection; the membrane is Thiéry-negative. (c, $d) M$. leprae in a skin biopsy from patient no. 2; the bacilli are under advanced lysis and the membranes (M) are Thiérynegative. PI, PAS-positive inclusions.

appropriate, had an asymmetric profile, with the outer layer (facing the cell wall) thicker and more electron-dense than the inner layer (facing the cytoplasm); we further found that such a profile changed to a symmetric one when the membrane was affected by diverse situations like bacteriolysis (either autolysis or heterolysis), or treatments with membrane-active agents (Silva, 
1967. 1975, 1984; Silva \& Macedo, 1982a, 1983b; Silva \& Sousa, 1972; Silva et al., 1976, 1978, $1979 a, b)$. In other words, in properly fixed Gram-positive bacteria, the presence of symmetric membranes in lead-stained sections indicates damaged membranes.

Consequently, our observation that ultrastructurally normal $M$. leprae in patients (Silva \& Macedo, 1982a; Silva et al., 1982a) and in experimentally infected armadillos (Silva \& Macedo, $1983 a$ ) had membranes with symmetric profiles in lead-stained sections, a result now confirmed and extended to the bacilli in nude mice, is quite surprising. The results presented in this paper make it necessary to re-evaluate our previous interpretation that the membrane of normal $M$. leprae is symmetric. First, the results of the Thiéry and PTA staining of mycobacterial membranes have to be considered. Although we do not know, at present, which molecules are responsible for the positive reaction observed with those procedures in the outer layer of all the cultivable species studied, it is likely that they could be equivalents of the surface amphiphiles found in the outer layer of the cytoplasmic membranes of Gram-positive bacteria (Wicken \& Knox, 1980). Such amphiphiles have sugar residues in the hydrophilic portion of the molecule (Wicken \& Knox, 1980) and it is possible that those carbohydrates are responsible for the Thiéry and PTA staining of the outer layer of the cytoplasmic membrane of all Gram-positive bacteria studied up to now: Mycobacterium (Petitprez \& Derieux, 1970; Silva, 1984; Silva \& Macedo, $1983 c$; the present work), Nocardia (Silva, 1984), Streptomyces (Silva, 1984), Bacillus (Rosseau \& Hermier, 1975; Silva, 1984) and Micrococcus (Silva, 1984; Silva et al., 1977). Consequently, our result showing that the membrane of $\boldsymbol{M}$. leprae that looks ultrastructurally normal has PASpositive components in both layers is striking, because it represents the only exception to the absolute asymmetry of PAS-positive molecules in bacterial surface membranes. Therefore we have now to consider alternative interpretations for the symmetric profile of $M$. leprae membrane. The possibility that the symmetric membranes we have seen in all normal-looking leprosy bacilli represent altered membranes deserves consideration because, as discussed above, damaged membranes of Gram-positive bacteria, including cultivable acid-fast bacteria, exhibit symmetric profiles. However, Thierry staining showed that the symmetric membranes of affected cultivable mycobacteria were Thiéry-negative, and the symmetric membranes of normal-looking $M$. leprae were Thiéry-positive. Moreover, $M$. leprae cells with ultrastructural signs of bacteriolysis had Thiéry-negative membranes. Therefore, if the symmetric, Thiérypositive membranes we have found in all $M$. leprae cells with the ultrastructural characteristics of normal mycobacteria were not the normal membranes of the leprosy bacillus, then they would represent a peculiar form of abnormal membrane not found in the cultivable species. Furthermore, if this were the case it would indicate that all the intact $M$. leprae we found by electron microscopy were abnormal. This would be a surprising conclusion mainly in the case of the untreated patients with high BI and MI. The finding that the liver of armadillo AU contained a few bacilli with Thiéry-asymmetric membranes can be explained by the recent observation by Portaels \& Pattyn (1982), who isolated unidentified cultivable mycobacteria from the livers of some experimentally infected armadillos.

At present it is difficult to decide whether the symmetric PAS-positive membranes seen in $M$. leprae cells with ultrastructural characteristics of normal mycobacteria represent normal or altered membranes, since both alternatives raise puzzling questions. This adds new facets to the peculiarity of the leprosy bacillus and implies that more work is necessary to clarify that point. Our results indicate, however, that there are some interesting differences in the ultrastructure of the membranes of the two most important human pathogenic mycobacteria: $M$. tuberculosis and $M$. leprae. To what extent such differences relate to physiology and pathology remains to be elucidated.

The authors are grateful to Drs M. Helena Costa, J. Torgal and H. Gonçalves (Hospital Curry Cabral, Lisboa) and to Dr A. Barbosa (Hospital Rovisco Pais, Tocha) for the biopsies from leprosy patients, to Dr H. L. David and P. Lagrange (Institut Pasteur, Paris) and to Dr Françoise Portaels (Institute of Tropical Medicine, Antwerpen) for the samples from animals experimentally infected with $M$. leprae and $M$. lepraemurium, and to Dr $H$. L. David for continuous support and helpful discussions. The excellent technical assistance provided by Miss $\mathrm{M}$. Irene Barros is gratefully acknowledged. We are grateful to Miss M. Andrea Costa for the help in the photographic work. The work was supported in part by Fundação Calouste Gulbenkian, JNICT (contract 435.82.110) and INIC (grant 
PB/1). The Elmiskop 102 used in the present work was a gift from Stiftung Volkswagenwerk (Hannover, West Germany).

\section{REFERENCES}

CoHn, Z. \& Benson, B. (1965). The differentiation of mononuclear phagocytes. Journal of Experimental Medicine 121, 153-169.

Colston, M. J. \& Hilson, G. R. S. (1976). Growth of Mycobacterium leprae and $M$. marinum in congenitally athymic (nude) mice. Nature, London 262, 399401.

Fléchon, J.-E. \& HunEAU, D. (1974). Validity of phosphotungstic acid staining of polysaccharides (glycogen) at very low $\mathrm{pH}$ on thin sections of glycol methacrylate embedded material. Journal de microscopie 19, 207-212.

JoPLING, W. H. (1978). Handbook of Leprosy, p. 9. London: Heinemann.

LUFT, J. H. (1961). Improvements in epoxy resin embedding methods. Journal of Biophysical and Biochemical Cytology 9, 409-414.

Petitprez, A. \& Derieux, J. C. (1970). Mise en évidence des polysaccharides sur quelque types de bactéries. Journal de microscopie 9, 263-272.

Portaels, F. \& Pattyn, S. R. (1981). Parameters influencing the in titro growth of $M$. lepraemurium. International Journal of Leprosy 49, 194-197.

Portaels, F. \& Pattyn, S. R. (1982). Isolation of fastidiously growing Mycobacteria from armadillo livers infected with Mycobacterium leprae. International Journal of Leprosy 50, 370-374.

Rambourg, A. (1971). Morphological and histochemical aspects of glycoproteins of the surface of animal cells. International Revien' of Cytology 31, 57-114.

RIDLEY, D. S. \& Jopling, W. H. (1964). Classification of leprosy according to immunity. A five group system. International Journal of Leprosy 34, 255-273.

Robertson, J. G., Lyttleton, P., Williamson, K. I. \& BATT, R. D. (1975). The effects of fixation procedures on the electron density of polysaccharide granules in Nocardia corallina. Journal of Ultrastructure Research 52, 321-332.

Roland, J. C. (1974). Cytochimie des polysaccharides végétaux: détection et extraction sélectives. Journal de microscopie 21, 233-244.

Rosseau, M. \& Hermier, J. (1975). Localization en microscopie électronique des polysaccharides de la paroi chez les bactéries en sporulation. Journal de microscopie 23, 237-248.

SiLva, M. T. (1967). Electron microscopic aspects of membrane alterations during bacterial cell lysis. Experimental Cell Research 46, 245-251.

Silva, M. T. (1971). Changes induced in the ultrastructure of the cytoplasmic and intracytoplasmic membranes of several Gram-positive bacteria by variations in $\mathrm{OsO}_{+}$fixation. Journal of Microscopy 93. 227-232.

SiLva, M. T. (1975). Ultrastructure of the membranes of Gram-positive bacteria as influenced by fixatives and membrane-damaging treatments. In Biomembranes - Lipids, Proteins and Receptors, pp. 255-289. Edited by R. M. Burton \& L. Packer. Webster Groves, Mo., USA: BI-Science Publication Division.
Silva, M. T. (1984). The use of transmission electron microscopy of ultrathin sections for the characterization of the ultrastructure of normal and damaged bacterial membranes. In Biomembranes: Dynamics and Biology. Edited by F. C. Guerra \& R. M. Burton. New York: Plenum Press (in the Press).

Silva, M. T. \& MACEDO, P. M. (1982a). Ultrastructure of Mycobacterium leprae and other acid-fast bacteria as influenced by fixation conditions. Annales de microbiologie 133B, 59-73.

Silva, M. T. \& MACEDO, P. M. (1982b). Comparative ultrastructural and cytochemical study of the membranes of Mycobacterium leprae and cultivable Mycobacteria. XVII Reunião Anual, Sociedade Portuguesa Microscopia Electrónica, abs. 26.

Silva, M. T. \& MACEDO, P. M. (1983a). Electron microscopic study of Mycobacterium leprae membrane. International Journal of Leprosy 51, 219-224.

Silva, M. T. \& Macedo, P. M. $(1983 b)$. The interpretation of the ultrastructure of Mycobacterium cells in transmission electron microscopy of ultrathin sections. International Journal of Leprosy 51, 225234.

Silva, M. T. \& Macedo, P. M. (1983c). A comparative ultrastructural study of the membranes of Mycobacterium leprae and of cultivable Mycobacteria. Biology of the Cell 47, 383-386.

Silva, M. T. \& SousA, J. C. F. (1972). Ultrastructural alterations induced by moist heat in Bacillus cereus. Applied Microbiology 24, 463-476.

Silva, M. T., Sousa, J. C. F., Macedo, M. A. E., Polónia, J. \& Parente, A. M. (1976). Effects of phenethyl alcohol in Bacillus and Streptococcus. Journal of Bacteriology 127, 1359-1369.

Silva, M. T., Polónia, J. J. \& Kocur, M. (1977). The fine structure of Micrococcus mucilaginosus. Journal of Submicroscopic Cytology 9, 53-66.

Silva, M. T., Sousa, J. C. F. \& Balassa, G. (1978). Ultrastructural effects of chemical agents and moist heat on Bacillus subtilis. I. Effects on vegetative cells. Annales de microbiologie 129B, 363-375.

Silva, M. T., Polónia, J. J., Macedo, M. A. E. \& MACEDO, P. M. (1979a). Membrane splitting induced by lipophilic molecules. Biologie cellulaire 35 , 175-182.

Silva, M. T., Sousa, J. C. F., Polónia, J. J. \& MACEDO,P. M. (1979 b). Effects of local anesthetics on bacterial cells. Journal of Bacteriology 137, 461-468.

Silva, M. T., Macedo, P. M., Costa, M. H. L., Gonçal ves, H., ToRgal, J. \& David, H. L. (1982a). Ultrastructural alterations of Mycobacterium leprae in skin biopsies of untreated and treated lepromatous patients. Annales de microbiologie 133B, 75-92.

Silva, M. T., Macedo, P. M., Salema, R. \& Santos, I. $(1982 b)$. Improvement in the Thiéry reaction by the use of silver vitelinate. XVII Reunião Anual, Sociedade Portuguesa Microscopia Electrónica, abs. 30.

THIÉRY, J. P. (1967). Mise en évidence des polysaccharides sur coupes fines en microscopie électronique. Journal de microscopie 6, 987-1018. 
Thiéry, J. P. \& Rambourg, A. (1974). Cytochimie des polysaccharides. Journal de microscopie 21, 225-232. Venable, J. H. \& Coggeshall, R. (1965). A simplified lead citrate stain for use in electron microscopy. Journal of Cell Biology 25, 407-408.
Wicken, A. J. \& KNox, K. W. (1980). Bacterial cell surface amphiphiles. Biochimica et biophysica acta 604, 1-26. 